УДК: 392.12(477.85)

\section{Антоній МОЙСЕЙ,}

ВДНЗ України «Буковинський державний медичний університет», Чернівці (Україна)

\author{
Antoniy MOYSEY \\ Higher State Educational Establishment of Ukraine \\ «Bukovinian State Medical University», \\ Chernivtsi (Ukraine), antoniimoisei@bsmu.edu.ua \\ ORCID ID: 0000-0001-5295-2271
}

\section{ОСОБЛИВОСТІ СПІЛЬНОГО ФУНКЦОНУВАННЯ ПОВИТУХИ ТА АКУШЕРКИ В РОДИЛЬНІЙ ОБРЯДОВОСТІ УКРАЇНСЬКОГО ТА РУМУНСЬКОГО НАСЕЛЕННЯ БУКОВИНИ}

\author{
SPECIFICS OF THE CONCURRENT \\ FUNCTIONING OF A MIDWIVES AND \\ OBSTETRICIANS IN MATERNITY RITES OF \\ UKRAINIAN AND ROMANIAN POPULATION \\ IN BUKOVYNA
}

Ключевые слова: Мойсей Антоний. Особенности совместного функционирования повитухи и повитуха, Моша, акушер- акушерки в родильной обрядности украинского и румынского населения Буковины. ка, Буковина, Черновицкая область, родильная обрядность

В предлагаемом вниманию читателя исследовании, на основе этнографических и статистических данных, характерных для Буковины, отслеживается процесс исчезновения одного из действующих персонажей родильной обрядности - повитухи (моши) под давлением новых реалий, созданных официальной медициной. Проблема рассматривается в компаративном ключе, с учетом многовекового сосуществования украинского и румынского населения в буковинской этнографической зоне.

Вступ. Визначальна роль в прийнятті новонародженого, догляді за породіллею та дитиною в традиційному суспільстві відводилась повитухи, названій у румун і в українців Буковини моша або моаша.

Історіографія та джерельна база дослідження. Проблема ролі повивальної бабки, повитухи чи моаші добре вивчена як українськими, так і румунськими етнологами. 3 українських авторів відзначимо роботи О. Боряк ${ }^{1}$, в яких використано широку джерельну базу, в тому числі власні польові матеріали, детально проаналізовано процес трансформації родильної обрядовості українців. Однак, маючи за мету вивчити цю проблематику в загальноукраїнському масштабі, автор використав незначний матеріал з Буковини. В монографії Н. К. Гаврилюк «Картографування явищ духовної культури (за матеріалами родильної обрядовості українців)»² проведена типологізація i картографування основних елементів родильної обрядовості більшості областей України. На жаль, західний регіон, разом з Чернівецькою областю, випали 3 поля зору авторки.

Наближеною до досліджуваної нами теми, є робота чернівецьких вчених-медиків Т. М. Бойчука, І. Д. Шкробанця, О. М. Юзька, О. А. Андрієць, I. Р. Ніцович "Історія розвитку акушерства та гінекології на Північній Буковині"', де розвиток акушерства в краї подається в ретроспективному аспекті, відслідковується процес еволюції акушерства як медичної галузі.

В дослідженнях румунських етнологів тема повитухи найбільш вдало розкрита в роботах Л. Бердан "Магічні практики віщування та ворожіння в родильних обрядах" Румунські іпостасі безсмертя» ${ }^{5}$.

Питання взаємовпливу традиційних культур українців і румунів в царині обрядів пов'язаних 3 родинами піднімалося в публікаціях автора даної статті в співавторстві з К. Парайко. ${ }^{6}$

Цінні відомості про інститут родопомочі, на рівні окремих буковинських сіл, наприкінці XIX ст. вміщено у фондах Державного архіву Чернівецької області. Архівні справи проливають світло на існування та діяльність повитух і акушерок в регіоні ${ }^{7}$, найбільш розповсюджених у II половині XIX ст., хвороб та причин смерті породілль, на діяльність генерального санітарного інспекторату Буковини ${ }^{8}$, акушерських шкіл ${ }^{9}$, лікарень, пологових будинків ${ }^{10}$ тощо. Ці відомості представляють цінність у контексті процесу поступового переходу населення від послуг баб-повитух до акушерок, заснування лікарень та пологових будинків, який йшов інтенсивно саме у другій половині XIX - на початку XX ст.

Серед архівних матеріалів, відзначимо рукопис монографії співробітника Чернівецького державного медичного інституту С.К. Лобинцева ${ }^{11}$, присвяченої розвитку медицини на Буковині, в якій містяться дані про процес трансформації ролі моаші на початку становлення радянської мережі медичної допомоги населення Буковини.

Окремий корпус документів складають матеріали рукописних фондів наукового архіву Чернівецького музею народної архітектури та побуту. Зокрема, серед них інтерес представляє "Звіт про етнографічну експедицію 3 вивчення народних традицій і побуту румунського населення Герцаївського району: Велика Буда, Байраки, Годинівка, Горбова, Тарнавка, Остриця, м. Герца", в якому вміщені матеріали, що представляють інтерес для вивчення діяльності та ролі повитух в обрядах, пов'язаних з народженням дитини ${ }^{12}$.

Значний пласт матеріалів про народну медицину румунів Буковини у другій половині XIX - на початку XX ст. зберігається у меморіальнодокументальному фонді будинку-музею С.Ф.Маріана у Сучаві (Румунія) $)^{13}$. Заслуговує на увагу також рукопис його праці «Родини у румунів». Етнографічний матеріал поділений на 25 розділів, один з яких названий «Стіл повитухи».

Не позбавлені наукового значення цілий ряд праць, які дають змогу провести порівняльну харак- 
теристику основних аспектів народної медицини румунів та українців Буковини. Так, у публікаціях Г. Купчанко ${ }^{14}$, де можна знайти фактаж медичного аспекту родильної обрядовості, дані щодо вживання назви моша на вказаній території.

У публікаціях австрійського етнографа Р. Ф. Кайндля ${ }^{15}$ знаходимо відомості про санітарний стан краю у ХІХ ст. У 2000 році була перевидана його праця "Гуцули", де окремим третім розділом "Цілительство" подані численні домашні лікувальні засоби, зокрема і "для викиду плоду"16. Дослідник спробував об'єктивно пояснити причини, через які гуцули не зверталися до представників офіційної медицини, а користувалися послугами знахарок та nовитух. Представляє інтерес також його спільна робота 3 О. Манастирським «Русини на Буковині» ${ }^{17}$, де вони проаналізували цикл родильної звичаєвості з медичної точки зору.

Локалізувати інформативну базу щодо населення Хотинського повіту Бессарабської губернії Російської імперії (бессарабської частини сьогоднішньої Чернівецької області), допоможуть роботи П. Нестеровського ${ }^{18}$, А. Защука ${ }^{19}$, П. Свіньїна ${ }^{20}$, В. Бутовича ${ }^{21}$, 3. Арбуре ${ }^{22}$, В. Моiсiу ${ }^{23}$ ňa ін. В них можна знайти фактичний матеріал про стан медичній галузі в краї, про протистояння офіційної медицини (акушерок) і народного цілительства (баб-повитух). Всі автори підтримали пріоритет методів раціональної медицини, їхню ефективність та безпеку для пацієнток.

Величезний фактологічний матеріал, зібраний шляхом польових досліджень в 1997- 2016 роках, накопичений в особистому архіві автора даної статті. Він стосується різних аспектів народної лікувальної практики румунів і українців буковинської етнографічної зони, в тому числі дослідженої тематики родильної обрядовості. Роль повитухи, як центральної постаті в процесі ведення вагітності та народження дитини і родильній обрядовості, знайшла в них своє об'єктивне висвітлення. До корпусу фактологічної бази слід віднести також дані I етапу конкурсу студентських науково-дослідних робіт з народної медицини, що проходив у 2013-2014 н. р. в Буковинському державному медичному університеті. У результаті проведення польових досліджень, була отримана етнографічна інформація 3 народної медицини, що походить з 65 населених пунктів України ${ }^{24}$.

Отже, історіографічний та джерельний матеріал дозволяє прослідкувати процес трансформації ролі повитухи (моаші) в протистоянні до офіційної медицини в історичному розрізі XIX ст. - першої половини XX століття на терені Буковини. Одночасно цей матеріал надає можливість провести компаративний аналіз між трансформаційними процесами в родильній обрядовості на порубіжжі двох культур: української та румунської.

Термінологія. Родопомічниці - це були досвідчені, компетентні в справі прийняття пологів жінки, переважно похилого віку, часто вдови. Вони раціональними, а також магічними засобами, допомагали породіллі при родах, також здійснювали низку сімейних обрядів. Типологізація народної термінології дозволила Н.К. Гаврилюк підсумувати розповсюдження назви повитухи наступним чином: у північних, східних та південних районах України їі називали баба, бабушка, бабка; на Правобережжі - бабкабранка; для Середнього Подніпров'я були характерні словосполучення, пов'язані з словами род, пуп, різати - баба-пупова, пупорізка, пупорізниця, породільна, piзна та ін. ${ }^{25}$ О. Боряк додає ще декілька назв - nовивальна бабка, акушерка (кушорка) або лікарка / лікар (дохтурка, мєдічка), характерних для перехідного періоду від повитухи до акушерки і гінеколога ${ }^{26}$. Наші польові дані підтверджують розповсюдження згаданих назв в україномовних областях України, однак на території Чернівецької області була більш розповсюджена назва моша в українських селах: Кам'яна, Спаська, Банилів-Підгорний, Чорнівка, Бабине, Онут, Добринівці, Верхні Станівці, Шипинці, Усть-Путила, Дихтинець, Старі Бросковці, чи моаша в румуномовних селах: Несвоя, Молодія, Стальнівці, Куліківка, Мамалига та ін. Назва моша проникла навіть за межи Буковини, наприклад, вона була відома в м. Хоростків Гусятинського району Тернопільської області. Зареєстрована також назва циарська жінка в селі Стаpi Бросківці ${ }^{27}$ та Нижніх Петрівцях Сторожинецького району Чернівецької області ${ }^{28}$. Типологізація назви родопомічниці, локалізується в південній частині Буковини назва моаша та изарська або сільська моа$m a^{29}$.

Етимологія. Григорій Купчанко, аналізуючи назви родичів, які існують на Буковині в українців, писав: «У буковинських подолян батько називається неньо, мати - мама, дід - дід, бабуся - моша...» ${ }^{30}$. Тлумачні словники дають пояснення цьому слову. В них однозначно відзначено, що моша - це «стара жінка», «бабуся», «прабабуся ${ }^{31}$, «та, що допомагає сільським жінкам при родах»: „Mărita-m-oi, mărita, / Pân-a trăi moșica” / «Віддамся я, віддамся / Поки жива мошика" ${ }^{132}$; „Frunză verde de pe coastă / Să trăiască moașa noastră” / «Лист зелений зі схилу / Най живе наша моаша» ${ }^{33}$. В традиційному суспільстві, моаша обиралася з роду (великий рід), а в невеликих громадах вона задовольняла потреби всього села. Слово вперше атестовано в XV ст. ${ }^{34}$, 3 чого багато авторів вбачають етимологію слова мош (стара людина, дід) від албанського моше «moshë» $(\text { вік,літній })^{35}$, або автохтонним, яке походить 3 албанської мови (А. Філіппіде, А. Россеті, І. Руссу, Ӑ. Бринкуш), навіть румунської, яке перейшло до угорської (masa), сербської та словенської мов ${ }^{36}$.

Виходячи $з$ широкого спектру думок лінгвістів в дослідженій нами сфері, особливий інтерес представляє проблема типологічних зв'язків албанської мови 3 мовами інших írđîäiв Балканського півострова наявність схожості в побудові деяких граматичних форм в албанській мові з румунською, болгарською і новогрецькою мовами. Енциклопедія Сучасної України визначає албанську мову як палеобалканську, генетично наближеною до іллірійської мови ${ }^{37}$. Дане положення підтверджується словником Ф.А. Брокгауза і I.A. Ефрона ${ }^{38}$ з поясненням того факту, що багато слів, походження яких не можна пояснити елементами індогерманської мови належать, очевидно, мові, 
якою розмовляли давні іллірійці до переселення в місця сьогоднішнього їх проживання; вони частково характерні також румунській мові, яка має з албанським споріднений етнологічний субстрат. Ця спорідненість, на думку румунського дослідника К. Маноїлеску, вбачається в фонетичній будові, морфологічній структурі, синтактичній конструкції, фразеології, формулюванні слів та словнику. 3160 слів, які вважаються дакськими в румунській мові, 90 слів існують також в албанській мові. Багато з них є базовими словами обох мов (brad, mânz, gât, buză...) та безумовно належать до архаїчного фонду ${ }^{39}$.

Виходячи зі сказаного, можна погодитись 3 поясненням В. Скурту, який вважає слово моша дороманського походження. На його думку, воно споріднене $з$ албанською формою та відноситься до іллірійсько-фракійсько-дакських мов, тобто належить до давнього карпато-балканського автохтонного фонду. Термін був запозичений з румунської мови болгарами, угорцями, українцями, поляками ${ }^{40}$

Основна частина. Польові дослідження, проведені на території південної частини Буковини, доводять, що повитухою могла бути матір породіллі; родичка, бабуся похилого віку; своячениця або бабуся жінки; стара уміла жінка ${ }^{41}$. Етнографічний опис краю Ватра Дорней, складової частини історичної Буковини, висвітлює загальну картину ролі моаші в сільському соціумі. Згідно цього опису, в кожному селі існувала одна авторитетна моаша, яка користувалася довірою більшості сімей, та 2-3 бабки, до яких зверталися тільки у випадках крайньої необхідності. Moaша була шанованою особою в громаді, будучи досвідченою жінкою похилого віку. За відсутності моаші, iii функції виконувались старшою жінкою з родичок. В гірських умовах, коли хата від хати знаходилась на досить далекій відстані, бували випадки, коли роди приймав чоловік, який чітко виконував вказівки своєї дружини $^{42}$.

О. Боряк, яка достеменно вивчила постать бабиповитухи в українців, визначила ії̈ як носія спеціальних народних акушерських знань, основною функцією якої було надання допомоги породіллі (як раціональними, так і ірраціональними засобами) під час пологів. Вона завжди була жіночої статі, переважно похилого віку, досвідчена, «знаюча», - джерелом ii практичних знань були як досвід власних пологів, так і інших жінок ${ }^{43}$. Народній акушерській практиці виявилися добре відомими такі ключові ідеї та концепції наукового акушерства, як мануальний вислід вагіни, методи активізації черевної мускулатури, поворот плода за ніжку, постава породіллі під час пологів, іiї психотерапевтичне заспокоєння, оживлення дитини, способи відтинання пуповини, спеціальні дії при кровотечі, затримці посліду, зрушенні матки тощо ${ }^{44}$.

Проведена нами польова розвідка показує, що кількість повитух у населених пунктах різнилася. Наприклад в українських селах: Кам'яна, Лівінці, Добринівці, румунських селах: Молодія, Мамалига зазвичай практикувала одна моаша. Наявність двох повитух зареєстровано в українських селах: Банилові -Підгірному, Шипінцях, Усть-Путилі, 2-3 повитухи - в румунському селі Несвої, м. Новоселиці (змішаний населений пункт), українських населених пунктах: Кельменцях, Чорнівці, Іспасі, Дорошівцях, Онуті, Нижніх Станівцях Кіцманського р-ну, Старих Бросківцях та ін. В українському селі Бабині Вижницького району п'ять повитух надавали допомогу породіллям в різних кутах села. Критерії підбору кандидаток на роль моші в межах сучасної території Чернівецької області були аналогічні як тим, що існували в українському етнічному просторі, так і тим, що були характерні для румунської сільської громади. «Бабка старшого віку, яка уміла це робити; спритна, уважна, чиста, акуратна; вміла дати раду породіллі; уміла приймати пологи та розумілася на травах; вона сприймалася сільською церквою», - ось основні вимоги до сільської родопомічниці на порубіжжі двох етнічних культур ${ }^{45}$.

Вагома автентична інформація в сфері родильної обрядовості, зібрана С. Ф. Маріаном в другій половині XIX ст. зі всіх куточків румунського етнічного простору, в тому числі з Буковини, дозволяє стверджувати що моаша була справжнім представником народної медицини. Вона як цілителька добре знала властивості різних трав та могла використати ці знання на практиці. Один з рецептів трав, який використовувала повитуха при купанні новонародженого, автор описав в роботі "Родини у румунів" (1892). За дослідником, моаша до горщика (обов'язково нового) додавала стеблину василька (зірваного у День Хреста), срібні монети, квітку півонії, господнє дерево, частку медового стільника, хліб та цукор, одне яйце, трохи молока та освяченої води. Всю суміш додавала до купелі новонародженого виголошуючи спеціальне заклинання ${ }^{46}$.

Перед початком пологів повитуха виставляла свій інструментарій. С. Ф. Маріан звернув увагу на одну деталь: моама, серед інших приладів, мала цівку (трубку), якою у випадку загрози життю жінки вдихала повітря у легені, або звільняла дихальні шляхи породіллі. Вона ж приймала дитину, різала пуповину, роблячи всі необхідні маніпуляції, мила новонародженого, перший раз годувала його через чисту ганчірку кислим молоком. Після цього вона масажувала все тіло жінки овечим маслом чи горілкою, потім, вставляючи маленьку подушку біля матки, обгортала iї широким поясом. Після цього моаша кип'ятила горілку з цукром та добре змеленими зернами жита і давала породіллі випити одну чи дві склянки ${ }^{47}$.

За С. Ф. Маріаном повитух кликали і до пологів, особливо якщо породілля хворіла. Представляє інтерес народна медична практика лікування: моаша брала 8-9 насінин кавуна та декілька гілочок щебрушки, подрібнювала їх та додавала у горілку або навіть воду та давала це випити вагітній. Після цього брала кілька лушпинь цибулі і клала їх на уламок 3 вугликами та обкурювала вагітну димом цибулі (Калафіндешти південної частини Буковини). У випадку переляку, вагітну обкурювали димом 3 ніздрів лисиці ${ }^{48}$

Матеріали наших досліджень підтверджують профанну частину дій моші. Коли вона заходила до хати породіллі їй давали теплу воду, ножиці, рушник, 
зеленку і нитку (с. Спаська Сторожинецького р-ну Чернів. обл., с. Попельники Снятинського р-ну ІваноФранків. обл.), повитуха здійснювала певні маніпуляції: масаж, розтирання, компреси (румун. села: Молодія Глибоцького р-ну, Мамалига Новоселицького рну Чернів. обл., україн. село Колінки Городенківського р-ну Івано-Франків. обл.); поїла породіллю спеціальним зіллям 3 трав (с. Гвіздець Коломийського рну Івано-Франків. обл.), обкурювала димом з засушених трав (с. Колінки, м. Красилів Хмельн. обл., с. Великі Дідушечі Стрийского р-ну Львів. обл.).

Інформатори с. Дихтинець Путильського р-ну загадали, що перед прийняттям пологів повитуха добре мила руки, обрізувала нігті, змащувала руки жиром. Інструментарієм їй служили ножиці та нитка.

Свої емпіричні знання моша використовувала i після пологів. Вона, в більшості з досліджених сіл, відвідувала породіллю і новонародженого за необхідності (румун. село Несвоя Новоселицького р-ну Чернів. обл., україн. села: Банилів-Підгірний Сторожинецького р-ну Чернів. обл., Гвіздець, Устечко Заліщицького р-ну Терноп. обл., м. Борщів Терноп. обл.), 2 3 дні після пологів (с. Онут Заставнівського р-ну Чернів. обл., м. Красилів), перший тиждень (румуни с. Молодія, українці с. Іспас Вижницького р-ну Чернів. обл.), 2-3 рази на місяць (с. Добринівці Заставнівського р-ну Чернів. обл.), до хрещення дитини (с. Бабине Вижницького р-ну Чернів. обл.), один місяць (с. Мамалига), протягом одного року (с. Кам'яна Сторожинецького р-ну, Усть-Путила Путильського р-ну Чернів. обл.). В с. Спаська вона давала породіллі горілку, поварену з кмином і цукром «щоб скорочувались болі». Моша брала активну участь в обряді «продажу дитини», що мали лікувальну мету, коли хвору дитину умовно «продавали» жінці, у якої всі діти були здоровими, чи родичам ${ }^{49}$.

Моаша виконувала весь сценарій магічного впливу на результати пологів, що був дуже важливим моментом в розумінні породіллі, як і в концептуальному світосприйнятті всього жіночого загалу. Це мало безумовний позитивний вплив на психіку жінки, яка знаходилась у стресовому стані. Повитуха виконувала примовляння на всіх етапах пологів та в процесі соціалізації дитини ${ }^{50}$. Це підтверджується результатами польових досліджень. Інформатор 3 с. Молодія Глибоцького району вказувала на сакральну частину дій повитухи: «вона приносила з собою хліб і свячену воду, зайшовши в дім хрестилася, читала спеціальну молитву. Потім в будинку розв'язувала всі вузли та відкривала замки на скринях, щоб відкрилися родові ходи». У Дихтинці Путильського р -ну моша, щоб прискорити пологи, на поперек породіллі прикладала теплі компреси; під час важких пологів жінку поїли чаєм з ромашки, календули, арніки. У Мамализі Новоселицького р-ну у минулому полегшували пологи за допомогою шматка глини, який прикладали породіллі до живота. У с. Нагоряни Камянець-Подільського р-ну (Хмельн. обл.), щоб полегшити пологи, повитуха відкривала всі замки, скрині, а влітку і двері. Схилившись над породіллею баба повторювала: “Ой, опростай, Боже, мою онученьку, їі душечку та роженцю, другу душечку та су- женцю"51.

В результаті своєї діяльності повитуха набувала високого соціального статусу в сільських громадах. Церква 3 нею співпрацювала та визнавала іiі, в селі іiі поважали, вона в нерідких випадках користувалася любов'ю своїх пацієнток. На родинах, купанні, хрестинах, весіллях, навіть при похованнях вона є одним 3 найбільш поважних персонажів. В більшості досліджених нами селах, повитухс також користувалися загальною повагою. Їх часто брали за «хрещену» (с. Банилів-Підгірний), вважали «другою мамою» (с. Мамалига, с. Кам'яна, м. Новоселиця, с. Старі Бросківці, с. Гвіздець), «бабусею» (румун. село Куликівка Герцаївського р-ну Чернів. обл.). Повитуху, як і породілль, після пологів вважали нечистими, і вони проходили в церкві обряд очищення (Спаська Сторожинецького р-ну, м. Новоселиця, Бабине Вижницького р-ну).

В деяких місцевостях існує спеціальне свято застілля моаші, де всі іiї «онучки» організовують для неї пригощання, віншування, танці ${ }^{52}$. Так, у Лівинцях Кельменецького р-ну повитуха була головною особою на родинах, саме вона накривала на стіл та приймала гостей. У деяких селах саме повитуха несла новонароджену дитину до церкви, де ії̈ передавала вінчальним батькам (Спаська, Чорнівка, Молодія, Мамалига, Куликівка). У с. Іспас та Бабине Вижницького р-ну, Верхні Станівці Кіцманського р-ну, Стаpi Бросківці Сторожинецького р-ну інформатори пам'ятають, що у разі важкої хвороби, новонароджену дитину повитуха могла навіть охрестити.

Bci описані обставини дали право румунському етнологу І. Гіною підсумувати роль моаші як такої, яка при народженні проводила безпомилково сакральні та профанні дії, призначені для приведення на цей світ новонародженого, його інтеграції в сім'ю та батьківський рід, гарантування здоров'я матері та дитини. Вона була сильною особистістю, най важливою у прийнятті рішень, шанованою суспільством за iii природні або здобуті працею якості. Вона виконувала об'єм роботи, якій сьогодні вирішується цілим пологовим закладом: готувала та допомагала жінці при родах, повивала дитину, повідомляла батькові стать дитини, здійснювала миття новонародженого, радила породіллі як годувати та доглядати дитину, доглядала, використовуючи знання та практику емпіричної медицини, за станом здоров'я породіллі та іiі сина чи доньки ${ }^{53}$. До аналогічних висновків в українському етнічному просторі прийшла i Н. К. Гаврилюк. Вона пояснювала вказаний феномен тим, що життя породіллі і новонародженого в традиційному селі багато в чому залежало від знань та досвіду повитухи, iіi вміння користуватися народною медициною. Не випадково, на іiі думку, повитуха, якщо іiї практика була успішною, користувалася загальною повагою односельців. До відчуття пошани приєднувались також різні магічні стереотипи, породжені тривогою та невпевненістю в благополучності результату пологів. Тому багато обрядодій, виконаних повитухою, розглядались як такі, що могли принести користь здоров'ю породіллі та малюка, наділити новонародженого позитивними якостями, вплину- 
ти на його долю, забезпечити благополуччя ${ }^{54}$.

Отже, як ми бачимо, суттєвих відмінностей у сприйнятті ролі повитухи-моші на фронтирі двох культур не відмічається. Вони були наявні тільки в назвах та кількості родопомічниць. Нічого дивного в немає, адже протягом століть ці два народи існували разом, впливаючи один на одного, змінюючи часом домінуючі ролі в просторі спільного проживання. Не дивно, що деякі дослідники нашого краю звертали увагу на цю особливість мешканців порубіжжя двох етносів. П. Нестеровський в 1910 р. ділився з читачами своїм подивом: «В'їдеш інколи в тутешнє село i сам не знаєш, серед кого опинився - малоросів чи молдаван. Довкола чуєш малоруську мову, натомість все молдавське, принаймні з зовнішнього боку. Цей дивний вплив народу, який за своїм інтелектом стоїть не вище, але навіть нижче русинів, не припиняється i тепер. На моїх очах відбувається під молдавським впливом зміна в селянському одязі, в розвагах тощо» ${ }^{55}$. Прискіпливий дослідник Бессарабії російської доби П. Казаку описав зовнішній вигляд бессарабських сіл, не виділяючи їх етнічної належності. «Зовнішньо вигляд сіл Бессарабії, - писав він, - 3 плотами та парканами; хатами, побілені вапном, помальовані арабесками та національними кольоровими візерунками, покриті очеретом, дранкою, або тонконогом; криниці зі звідами, цебрами та гаками; селяни у сіряках і качулах, серед узгір'я холмів, покриті кукурудзою чи пшеничними полями, - загальний вигляд людей і сіл зоставався незмінно молдавським століттям 3 усіх боків, як і довкілля» ${ }^{56}$. Чи можна було тут провести чітку межу в звичаях, обрядах та матеріальній культурі між двома народами? Звісно, що ні! Обидві культури вбирали найкращі за формою та найбільш практичні за змістом елементи традиційної обрядовості, не звертаючи особливої уваги на їх етнічну складову. В XIX столітті населення краю гуртувалося за конфесійним принципом, тому спільність в християнстві знімала психологічний бар'єр у дифузійному процесі взаємопроникнення традиційних культур.

Перший сигнал небезпеки для домінантного існування повитухи в родильній обрядовості пролунав разом з початком епохи Просвітництва. Ідеї Просвітництва знайшли в кінці XVIII - першій половині XIX ст. своїх прихильників у всіх трьох імперіях (Австрійська, Російська, Османська), до складу яких входила територія сучасної Чернівецької області. Характерною рисою Просвітництва було прагнення його представників до перебудови всіх суспільних відносин на основі розуму, вічної справедливості, рівності та інших принципів, що, на їх думку, випливали 3 самої природи, 3 невід'ємних «природних прав» людини.

Рушійною силою історичного розвитку і умовою торжества розуму просвітителі вважали розповсюдження передових ідей, знань, а також поліпшення морального стану суспільства. В цій логіці ідей розвиток медицини співпадав 3 прагненням покращити санітарний стан міст та сіл, дбати про здоров'я своїх громадян. Відтак, серед очільників держав стало «модним» бути «просвітленим» монархом, який по-батьківськи дбає про благополуччя своїх підлеглих. Нові віяння цієї історичної віхи стали відчутними і на території Буковини, яка з 1775 р. стала складовою частиною Австрійської імперії.

В доповідній записці першого голови австрійської військової адміністрації Буковини Габріеля фон Сплені дається опис санітарно-адміністративної справи в краї на той момент. «Все, що належало до санітарної служби, було запущене, - пише він, - ніде, крім Ясс, не було ні цирульника, ні хірурга, ні лікаря взагалі, а про аптеки не було й чутно. Вагітні жінки під час пологів кожного разу ризикували життям. Забобони і невігластво замість належної допомоги проти природної небезпеки часто прискорювали смерть» ${ }^{57}$ С. Смаль-Стоцький в своій роботі «Буковинська Русь», оцінюючи стан справ в краї на момент приходу австрійців, констатує: «про лікарів, акушерок, шпиталі тут ніхто не чував; За град палили 1785 р. в Яблониці, Конятині, Довгополі відьми, за посуху (1790) топили їх в Шерівцях і Вербівцях» ${ }^{58}$. У 1780 р. другій військовий губернатор Буковини генерал Енценберг вніс пропозицію організувати підготовку акушерок для потреб краю, але австрійський уряд відхилив іii. У 1783 р. санітарний радник крайового управління отримав дозвіл на організацію підготовки акушерок для Буковини. Однак, не знайшлось жодної жінки, яка побажала б навчатися цієї професії. Тільки в 1786 р. йому вдалося набрати декілька жінок для навчання. Викладання здійснював один лікар та старша акушерка. Навчання на початковому етапі велося на німецькій, згодом і на польській мо$\mathrm{Bi}^{59}$.

31788 р. на Буковині була запроваджена нова адміністративна посада окружної акушерки, на яку була призначена Марія Теодорин. В тому ж році була відкрита перша лікарня в Чернівцях, а 31809 р. при ній почало функціонувати пологове відділення, в якому проходили практичну підготовку акушерки, в 1811 р. відкрита Чернівецька акушерська школа. Вона знаходилась разом з пологовим відділенням лікарні і гуртожитком для персоналу. Кількість студентів не перевищувала 30 -ти осіб ${ }^{60}$.

На той час, в суспільній думці буковинців, акушерство користувалось недобрим авторитетом. Воно вважалося, в певному сенсі, аморальним заняттям. Відношення панівних кіл до акушерства було зневажливим. Листування між директором Чернівецької гімназії Антоном Краль і Крайовим управлінням, де він просив перенести місце знаходження акушерської школи, оскільки «ії перебування в одному приміщенні з гімназією розбещує учнів гімназії» ілюструє якомога краще негативне сприйняття, навіть освіченими людьми, нової галузі медичної допомоги для населення. Тому і набір до акушерської школи був невеликим, а користування пологовим відділенням - обмеженим.

До послуг пологового будинку звертались, як правило, тільки в особливих випадках, в основному жінки 3 незаможних прошарків населення. Лікування тут було платним i тільки в особливих випадках $\mathrm{i}$ тільки вкрай нужденним надавалась безкоштовна допомога, однак при умові, що ці жінки мали в обо- 
в'язковому порядку служити об'єктом, на якому вчилися вихованки акушерської школи ${ }^{61}$. Заможні люди користувалися послугами досвідчених та наближених до цих сімей повитух. Тим більше, що породіллі при прийомі пологів моашою суб'єктивно довіряли як іiі фаховим навичкам, так і тим магічним діям, що супроводжували цей процес. До офіційної медицини населення ще ставилось 3 упередженням.

Австрійська влада, натомість, проводила рішучий наступ на повитух. В 1807 р. Львівське губернаторство вимагало встановити жорсткий контроль за діяльністю баб-повитух. В 1808 р. вийшла Інструкція для акушерок, яка описувала їх повноваження. Зокрема, практикувати в сфері акушерства і гінекології дозволялося лише дипломованим особам, діяльність яких контролювалася владою. Їм також заборонялось виконувати або сприяти абортам. 1866 року в Чернівцях відкрився пологовий будинок, й акушерська школа переходить в його підпорядкування. В крайовому пологовому будинку при відкритті було 15 ліжок, в 1911 році їх стало $25^{62}$.

В бессарабській частині нашого краю медичні заклади виглядали набагато гірше. За оцінкою П. Свіньїна, в 1816 р. медичний стан Бессарабської області був жалюгідним. 3 дня заснування в Кишиневі медичної управи в 1813 р., до 1816 р. складалася вона 3 одного міського лікаря, бо інспектор більше року був відсутній і тільки в тому році прибув туди «оператор» (тобто, хірург). В інших містах, окрім Ізмаїлського та Скулянського карантинів, штатні лікарі були відсутні. Тому, за словами Свіньїна, жителі при хворобах змушені звертатися до шарлатанів, старих бабок. Ліків у всьому краї ніде не можна було знайти, крім як в двох військових аптеках в Кишине$\mathrm{Bi}^{63}$.

Запровадження 1864 р. у Російській імперії управлінської земської реформи також позначилося пошуками нових форм надання акушерської допомоги, зокрема, апробовувалися системи роз 'їного та стаціонарного медичного обслуговування населення. Було поставлено завдання спеціальної підготовки кадрів родопомічниць.

Д. П. Кострицький, лікар, який в першій половині 1890-х рр. проводив медичні дослідження у всіх населених пунктах Романкоуцької волості, охарактеризував стан медичної справи у всьому Хотинському повіті. Весь повіт, за його словами, був поділений на 7 лікарських дільниць, в 2 з яких були по 25 ліжок, а в решті п'яті дільницях існували прийомні покої на 4 ліжка в кожному. В кожній дільниці працював постійний лікар, який завідував покоєм та виїзджав не менш як два рази в місяць на фельдшерські пункти. Крім земських лікарень, за його свідченням, ще існували дві приватні лікарні: поміщика Казимира в с. Васкоуцях на 5 ліжок і поміщика Крупенського в с. Ломачинцях. При обох медичних закладах були постійні лікарі, автор дослідження працював лікарем в Ломачинцях. Медична допомога в приватних лікарнях була безкоштовною ${ }^{64}$.

Діяльність повивальних бабок регулювалася на законодавчому рівні. Так, указ імператора Олександра III визначав порядок призначення та звільнення повивальних бабок (1881). Законодавчий посібник під назвою “'Звід законів і урядових розпоряджень щодо повивальних бабок, сільських повивальних бабок та повитух" (1886) спеціально забороняв тим, хто отримав кваліфікацію “сільська повивальна бабка”, практикувати в містах. Циркуляр "Поліпшення умов служби сільських медичних чинів” (1915) також визначив коло обов'язків акушерки $^{65}$. Для підтримки повивальної справи в містах було засновано низку медичних товариств зі своїми статутами, де, зокрема, йшлося про необхідність удосконалення професійної підготовки повитух. Проте запроваджені заходи виявилися недостатніми й на початок XX ст. у сільській місцевості повсюдно переважала практика ненавчених повитух.

У 1873 р. «Кишинівській єпархіальний вісник» друкує дорожні замітки священика С. Богословського, який описав свої враження від спостереження земських лікарів та акушерок. «Це прискорбне явище і його недоцільність, необгрунтованість у нас земської медицини цілком і повністю пояснює ту зневіру та холодність до нас з боку селян», - підсумував він свої враження від побаченого, - d'ияцтво старост і сотників як буденна реальність. А мандрівний лікар, який тут може практикувати, за словами священика, асоціюється у селян 3 тою «несимпатичною особою, яка в минулому жахала людей процесом перетаскування мертвих тіл з хати до хати та їх анатомуванням». Далі він розповів про побачене ним прийняття пологів у сільських умовах повитухою. Будучи запрошеним напучувати хвору, Богословський побачив жахливу картину: «вмираюча жінка, яка ніяк не могла розродитися, була прив'язана до сволоку стелі хати таким чином, що вона ледве торкалася пальцями ніг землі. Наслідок - смерть мами і дитини» ${ }^{66}$. На жаль, таких випадків невдалої роботи моамі було дуже багато на всій території Буковини і Бессарабії. Це викликало справедливе невдоволення і критику з боку офіційної медицини, створювало негативний авторитет повитухам.

На початку ХХ ст. В.П. Семенов-Тяньшанський реєстрував наявність в Хотині 3 лікарень на 18400 осіб населення ${ }^{67}$. Якщо порівняти ставлення влади до медицини на Австрійській та Російській частинах сучасної Чернівецької області, то слід сказати, що воно було подібним 3 тією різницею, що австрійці упроваджували іï більш швидкими темпами та з німецькою акуратністю, а росіяни повільними темпами та 3 провінційною недбалістю.

Однак поступ медицини офіційної та позиції медицини емпіричної тривав невпинно. Якщо в 1849 p. на Буковині (звісно, більша частина в Чернівцях) працювало 20 лікарів та один лікар припадав на 17154 особи населення, то в 1870 році їх стало 65, а 1906 р. -150. Зростала й кількість акушерок: на початку 1870-х років на Буковині їх було вже 150 осіб. При цьому, дуже незначна їх частина перебувала на службі в якості дільничних акушерок, більшість 3 них обслуговувала заможні верстви населення, займаючись приватною практикою. Зростання кількості акушерок стає помітним на початку XX ст.: у 1906 p. було зареєстровано 449 акушерок, які практикува- 
ли на Буковині. Але відсоток тих із них, які працювали в системі дільничного обслуговування залишався незначним $^{68}$.

Поступово зростає і авторитет акушерок, яких в народі називали старою назвою моаша. Акушерка заробляла в середньому від 40 до 160 крон в рік, а в селах іноді і до 200 крон. Часто вони задовільнялися лише тим, що бідна сім'я була спроможна дарувати їм після пологів.

До 1914 р., коли розпочалася Перша світова війна (1914-1918), Чернівецька акушерська школа випустила близько 500 фахівців. У 1913 р. в Чернівцях відкрився новий пологовий будинок, який продовжив працювати і в румунський період. Всього акушерська школа, за весь час свого існування, випустила майже 1000 спеціалістів. Вони почали приймати пологи в повітових лікарнях. Однак, більша частина міщанок і майже всі сільські жінки продовжували народжувати вдома, звертаючись до повитух, які не мали медичної освіти, але в більшості своїй добре могли впоратися 3 прийманням пологів. Тільки більш заможні сім'ї користувалися послугами приватних лікарів та акушерок. Смертність новонароджених залишалася високою $-33 \%{ }^{69} .30 \%$ всіх акушерок краю були сконцентровані в Чернівцях. Майже половина сільських населених пунктів була позбавлена навіть платної медичної допомоги. У 1892 р. від загальної кількості чернівчанок, які народили, до пологового будинку звернулися 6,5\%, в 1900 році - 6,6 \%, в 1906 р. $10 \%{ }^{70}$. Тому роль моаші залишалася на той час переважною.

Отже, до початку Першої світової війни, як на території Буковини, так і в Хотинському повіті Бессарабської губернії, всупереч факту зростання кількості лікарень, лікарів та акушерок, моаша домінує в сфері надання допомоги породіллі в найбільш відповідальний та вирішальний для неї та для її сім'ї момент життя. Моаша представляє на цьому етапі народну медицину в своєму емпіричному варіанті із значною частиною допоміжної магії, хоча і піддається нищівній критиці з боку офіційної влади та дипломованих спеціалістів в галузі акушерства і гінекологіï.

У 1918 đ. пłńё розпаду Австро-Угорської та Російської імперій наш край став складовою частиною королівства Румунії. Після Першої світової війни, в результаті якої рівень життя населення став катастрофічно низьким, санітарний стан краю був у тяжкому стані. Епідемії та соціальні хвороби забирали тисячі людських життів. Демографічні показники, зокрема дитяча смертність, відображали в повному об'ємі цю складну ситуацію.

Проміжні заходи, які приймала румунська адміністрація, не дали суттєвих результатів для покращенні стану справ. Вважається, що «Санітарний закон охорони» проф. Молдована 1930 року став моментом позитивного зрушення в сфері охорони здоров'я, особливо на селі. Згідно з цим законом, були створені санітарні округи, наділені профілактичними повноваженнями. В кожному такому окрузі мав бути один лікар на 1000 сільського населення. Діяльність лікарів мала бути направлена на зменшення дитячої смертності та соціальних хвороб. У порівнянні з 1918 р., коли подібних округів по всій Румунії було 400, в 1944 р. їх стало $1200^{71}$. В нашому краї ситуація була аналогічна тій, що існувала у всій Румунії. До того виникали нові надзвичайні ситуації. В 1921 р. під час величезної пожежі в Хотині згорів головний корпус повітової лікарні. Тільки в 1935 р. був збудований новий головний корпус. Наприкінці 1930-х рр. Хотинський повіт ділився на 28 санітарних ділянок, в яких працювало 28 лікарів, 56 фельдшерів, 32 акушери. Лікарні діяли в Хотині, Новоселиці, Кельменцях, Романківцях, Сокирянах ${ }^{72}$. На початку Другої світової війни в Хотині розпочала свою діяльність школа медсестринства, яка давала освіту в галузі акушерст$\mathrm{Ba}^{73}$. Якщо до війни на Буковині нараховувалося майже 500 акушерок, то в 1922 р. їх було не більше 150, а наприкінці 1930-х рр. ця кількість зменшилася до 100 осіб. Внаслідок зменшення кількості акушерських кадрів зросла дитяча смертність. 3 метою виправлення такої негативної ситуації румунська адміністрація зобов'язувала випускниць акушерської школи відпрацювати 5 років після завершення навчання у селі ${ }^{74}$.

Покращення ставлення до акушерок в середовищі простих людей не відчувалося. Однією $з$ причин цього може бути висока платня за перебування у лікарні. Зокрема, усі пацієнти були поділені на 3 класи. Вартість ліжко-місця на добу становила 75 леїв для I класу, 50 - для II класу і 25 - для III класу. Одночасно не можна стверджувати, що платне лікування у пологових будинках було основною причиною холодного відношення жінок до допомоги під час пологів з боку офіційної медицини. Варто звернутися до анкетування, проведеного С. Верхратським, хірургом за фахом, який проводив етнографічні дослідження з народного акушерства в 1920-х роках на Україні. Оскільки процеси, які відбувалися в різних країнах в сфері трансформації народного сприйняття акушерства майже ідентичні, вважаємо ці дані дуже цікавими. С. Верхратський своїм спеціальним анкетуванням хотів вивчити причини відмови селянок від професійної допомоги. Аналіз анкет довів, що 3500 селянок боялись акушерок, 83 - не звикли до них звертатися, 78 відповіли що «кушерка» далеко знаходиться, 263 жінок не бачили необхідності звертатися за такою допомогою. Крім того, відмічалось що транспортування акушерки було ускладненим, а забезпечення чистою білизною у великій кількості для селянського господарства також створювало складності. Окрему увагу дослідник звернув на те, що акушерка не виконувала низки обрядових дій ${ }^{75}$.

Таким чином, не стільки вартість, скільки психологічний поріг переходу до іншої форми медичної допомоги, в якій був відсутній також і магічний компонент, був бар'єром до використання послуг більш цивілізованої форми прийняття пологів. Тут проходила межа між двома цивілізаційними сприйняттями світобудови: сакральним і профанним. Чисто раціональна методика прийняття пологів не сприймалася на психологічному рівні. Тільки довгий період існування акушерства як медичної галузі, з явною перевагою в результатах приймання пологів, міг призвес- 
ти до корінних зрушень в психологічному сприйнятті жінок акушерства і гінекології в сфері медичної допомоги. Але до Другої світової війни цього зрушення, на жаль, не відбулося.

Після Другої світової війни стан справ з медичним обслуговуванням краю був дуже складним: були закриті дві поліклініки, три амбулаторії, консультації для жінок і дітей, дитячі ясла; зменшена кількість ліжок у лікарнях (наприклад, в обласній, дитячій лікарні та пологовому будинку кількість ліжок зменшилося до $60 \%)^{76}$. Міська лікарня була перетворена на військову казарму. Така ж ситуація спостерігалася і в районних центрах та селах: медичні установи пограбовано, закрито чи скорочено. Із 405 лікарів в області залишилося лише 120 осіб, інших розстріляно або вислано за межі Буковини, середніх медпрацівників залишилось одиниці ${ }^{77}$.

Не дивлячись на тяжкі повоєнні умови, відновлення мережі лікувальних закладів в області та збільшення кількості медичних працівників прийняли прогресуючий характер. В 1944 р. на 10 тис. населення в Чернівецькій області приходилось 4,8 лікарів (22,4 - в містах та 0,9 в селах), а вже в 1948 р. на 10 тис. населення приходилось 10 лікарів, але різниця між містом і селом зберігається великою. Акушерок у всій області нараховувалося 274 осіб, з них в Чернівцях - 65, у селах - 209. В містах до жіночих консультацій звернулись 4628 вагітних, в селах 1706 жінок. В селах вагітні жінки ставали на облік в більш пізні строки, тоді як в містах в більш ранні ${ }^{78}$.

З 1945 р. почалась інтенсивна відбудова та організація нових лікувальних закладів, у тому числі, i пологодопоміжних. Було відкрито 5 пологових будинків, нараховувалось 310 акушерських ліжок, 292 фельдшерсько-акушерських пунктів. У 1946 р. на 135 ліжок працювало 10 лікарів, зареєстровано 2578 пологів, 10 кесарських розтинів, 10 плодоруйнівних операцій, 29 випадків накладання акушерських щипців $^{79}$.

Така динаміка спостерігалася до кінця 1940-х років, вона була продовжена в 1950 -х роках. Протягом цього історичному відтинку часу, особливо на початковому етапі, у породіллі зберігалася можливість вибору між акушеркою і повитухою. Масовий характер приймає практика акушерок запрошувати під час пологів повитух $x^{80}$. Були навіть випадки суміщення цих двох ролей. Наприклад, в селі Печеніжин Коломийського району Івано-Франківської області Ганна Вакарчук була одночасно бабкою та санітаркою в лікарні 81 .

Процес витіснення повитух акушерками у кожній області - районі - селі мав свою специфіку. Його інтенсивність визначалася різними факторами - не останню роль відігравали, приміром, природні умови розташування того чи іншого населеного пункту, віддаленість від міста, стан доріг, наявність медичних кадрів та доступність акушерської допомоги тощо.

Приблизно з 1940-1950-х рр. поступово зникає потреба в повитухах; з'являються перші акушерські пункти, а пізніше пологові будинки. Однак у деяких місцевостях Буковини певна кількість жінок продовжувала народжувати вдома до 1960-1970 pр Поступово забуваються звичаї і обряди у виконані повитух. В основному, на даному етапі, у населення Сторожинецького району залишилась лише згадка про їх існування. Наприклад, під час опитування, румуни м. Сторожинця згадали про «мошу Москалашку 3 Ділки (один 3 кутів Сторожинця)», яка приймала пологи ще до Другої світової війни і вважається ними останньою професійною повитухою $^{82}$. У с. Тарасівці Новоселицького р-ну Чернів. обл., наприклад, 3 кінця 1940-х рр. працював пологовий будинок в одній з хат розкуркулених селян. Всі вагітні жінки були на обліку і до пологів їх на дому відвідували медсестри. Моаші вже не практикували під тиском влади (Інформатор: Мойсей Любов Герасимівна, 1933 р. н.).

Висновки . Виходячи 3 наявного фактологічного матеріалу, можна стверджувати, що 3 другої половини XIX ст., в нашому краї (як в австрійській, так і російській частинах) посилився тиск офіційної соціально-медичної системи на повитух. Доведено, що комплекс заходів проводився на рівні державної політики, регіональних проектів і програм, навчальних закладів, а також з ініціативи медиків і громадських діячів. Така політика була продовжена також при румунській адміністрації. Активне запровадження державної політики 3 охорони здоров'я жінки знайшло своє продовження за радянських часів: відкриття фельдшерськоакушерських пунктів, колгоспних пологових будинків, 3 одного боку, та адміністративний примус зайнятися родопоміччю для повитух.

Але співіснування акушерок і повитух, яке тривало десятиліттями, мало переважно неагресивний характер. Повитухи були підтримані православною церквою. В свою чергу, вони використовували церковну атрибутику, брали участь в церковних обрядах. Цей фактор був використаний атеїстичною радянською владою як додатковий аргумент в процесі заборони діяльності повитух. Починаючи з 1950-х років їх практика в нашому краї зникла.

Етнічний компонент на фронтирі двох культур не залишив помітних слідів на термінології, весь процес родопомочі, обряди та дійства післяродового періоду. Навпаки, ми можемо відмітити процес акультурації в цій сфері народної культури та майже суцільну дифузію обрядодійств в українців румунів Буковини.

\section{References:}

${ }^{1}$ Boryak O. Baba povy`tuha v kul'turno-istory`chnij trady`ciyi ukrayinciv: mizh profanny`m i sakral’nym / Olena Boryak. Kyiv: Instytut mystecztvoznavstva, fol'klorystyky' ta etnologhii im. M.T. Ryl’s kogo NAN Ukrainy`, 2009. - 400 s.; Boryak O. Tradycijna kul'tura ta novaciyi za radyans'koyi doby: osoblyvosti spivisnuvannya povytuxy ta akusherky u 2070-x rokax XX st. / O. Boryak // Etnichna istoriya narodiv Evropy. - 2009. - Vyp. 29. - S. 11-21.

2 Gavrylyuk N.K. Kartografuvannya yavyshh duhovnoyi kul'tury (za materialamy rodyl’noyi obryadovosti ukrayinciv. Kyiv, 1981. - 279s.

${ }^{3}$ Bojchuk T.M., Shkrobanecz I.D., Yuz`ko O.M., Andriyecz O.A., Niczovych I.R. Istoriya rozvytku akusherstva ta gineko- 
logiyi na Pivnichnij Bukovyni / T.M. Bojchuk, I.D. Shkrobanecz ta in. // Neonatologiya, hirurgiya ta perynatal'na medycyna. - 2013. - T. 3. - N. 4. - S. 153-159.

${ }^{4}$ Berdan L. Practici magice augurale și de divinație în obiceiurile de naștere / Lucia Berdan // Anuarul Arhivei de Folclor (1994-1996). - Cluj-Napoca: Editura Academiei Române, 1996.

${ }^{5}$ Ghinoiu I. Lumea de aici, lumea de dincolo. Ipostaze românești ale nemuririi / Ion Ghinoiu. - București: Editura Fundației culturale române, 1999. - 330 p.

${ }^{6}$ Moysey A., Parajko K. Rol' ta funkciyi povytuxy v rodyl'nij obryadovosti ukrayinciv ta rumuniv Storozhyneczkogo rajonu / A. Moysey, K. Parajko // Nauka i osvita: krok u majbutnye. Materialy VI Mizhnarodnoyi naukovoyi konferenciyi «Kajndlivski chytannya», prysvyachenoyi 145-richchyu vid dnya narodzhennya R.F. Kayndlya (m. Chernivci, 29 kvitnya 2011 r.). - Chernivci-Vyzhnycya: Cheremosh, 2011. - S. 368372; Moysey A., Parajko K. Ohoronni ta ochysni rytualy dlya materi i dytyny ta «pryednannya» novonarodzhenogo do sim'yi, gromady v obryadovosti ukrayinciv Bukovyny / A. Moysey, K. Parajko // Bukovyns 'kyj zhurnal. - 2011. - N. 3. - S. 186-194; Moysey A., Parajko K. Kompleks zaboron ta prypysiv, pov'yazanyj $\mathrm{z}$ vagitnistyu $\mathrm{v}$ ukrayinskogo ta shidnoromans 'kogo naselennya Bukovyny / A. Moysey, K. Parajko // Pytannya starodavn oyi ta seredn 'ovichnoyi istorii, arheologii i etnologhii (zbirnyk naukovyh pracz'). - Chernivci-Vyzhnycya: Cheremosh, 2011. - Tom 2 (32). - S. 166-177.

${ }^{7}$ Derzhavnyi arxiv Cherniveczkoyi oblasti (SAChR). - F. N. 401. - Op. 1. - Spr. 67. - 29 ark.; SAChR. - F. N. 1. - Op. 2. Spr. 311; SAChR. - F. N. 3. - Op. 2. - Spr. 12612;

${ }^{8}$ SAChR. - F. N. 286. - Op. 2. - Spr. 305;

${ }^{9}$ SAChR. - F. N. 3. - Op. 2. - Spr. 10915;

${ }^{10}$ SAChR. - F. N. 3. - Op. 4. - Spr. 2198.

${ }^{11}$ SAChR. - F. N. R-938. - Op. 5. - Spr. N. 45 A.

12 Naukovyj arxiv Cherniveczkogo muzeyu narodnoyi arhitektury ta pobutu. - NF. $-01-03-95$ a. -33 ark.;

13 Memorial'no-dokumentalnyj fond budynku-muzeyu S.F. Mariana v Suchavi (Rumuniya). Fond rukopysiv.

${ }^{14}$ Kupchanko G. Yzъ sbornyka bukovyns kyh prostonarodnyh pesen, skazok, povestei, poslovyczъ, sueveryj i pr.// Bukovynskaya Zorya. - 1870. - 9 fevralya; Kupchanko G. Nekotoriya istoryko-geografycheskiya svedeniya o Bukovyne. - K.: Typografyia M.P. Frycza, 1875. - 315 s.; Kupczanko G. Krankheitsbeschworungen bei russischen Bauern in der Bukowina // Am Ur-Quell. - Hamburg, 1891. - B. II. - Hf. 1. S. 12-14;

${ }^{15}$ Kaindl R.F. Geschichte von Czernowitz von den altesten Zeit bis zu Gegenwart. - Czernowitz: Uniwersitats - Buchhandlung H.Pardini, 1908. - 227 s.; Kaindl R.F. Zauberglaube bei den Ruthenen in der Bukowina und Galizien // Globus. Braunschweig, 1892. - LXI. Band. S. 279 - 282; Kaindl R.F. Die Huzulen // Herzogthum Bukowina in Wort und Bild. Wien, o. j. - S. 171-282;

16 Kaindl R.F. Guczuly: yix zhyttya, zvychayi ta narodni perekazy. - Chernivci: Molodyj bukovynecz, 2000. - 208 s.;

${ }^{17}$ Kaindl R., Manastyrs 'kyj O. Rusyny na Bukovyni»/ pereklad z nim. V. Ivanyuka, pislyamova M. Chuchka / R.F. Kaindl, O. Manastyrs 'kyj. - Chernivci: Zelena Bukovyna, 2007. - 192 s.

${ }^{18}$ Nesterovskyj P.A. Na severe Bessarabii. Putevye ocherky. Varshava: Izd. avt.,1910, S. 66.

${ }^{19}$ Zashhuk A. Materialy dlya georgafiy i statystyky Rossii, sobrannye ofyceramy General'nogo shtaba. Bessarabskaya oblast`. - Sankt-Peterburg: Russkoe geografycheskoe obshhestvo, 1862, S. 514.

${ }^{20}$ Svyn `yn P. Statystyka. Opysanye Bessarabskoj oblasty. 1816 // Zapysky Odesskogo obshhestva istorii i drevnostej. Odessa: Gorodskaya typografya X. Aleksomaty. - 1867. - Tom 6. - S. 176-283.
${ }^{21}$ Butovych V.N. Materyaly dlya etnograficheskoj karty Bessarabskoj gubernii. - Kyev: Skoropechatnya X.Yu. Burshtejna, 1916, S. 1-30.

${ }^{22}$ Zamfir C. Arbure. Basarabia în sec. XIX. - București, 1898. $-774 \mathrm{p}$.

${ }^{23}$ Moisiu V. D. Știri din Basarabia de astăzi. - București: Editura și Institutul de arte grafice C. Sfetea, 1915. - 102 p.

${ }^{24} 12$ oblastej Ukrainy: Vinnyczkoyi, Volyns'koyi, Zhytomyrs 'koyi, Zakarpats koyi, Ivano-Frankivs koyi, Kirovograds`koyi, L'vivs`koyi, Rivnens`koyi, Ternopil’s'koyi, Xmel'nycz'koyi, Chernivecz'koyi ta Chernigivs 'koyi.

${ }^{25}$ Gavrylyuk N.K., vkaz. pracya, S. 67.

${ }^{26}$ Boryak O. Tradycijna kulitura ta novaciyi..., vkaz. pracya, S. 1.

${ }^{27}$ Pol’ovi materialy avtora zibrani pid chas ekspedycijnyh doslidzhen ' u 1997-2016 rr. v ukrayins'kyh ta rumuns'kyh selax Chernivecz koyi oblasti Ukrainy ta Suchavs 'kogo povitu Rumunii.

${ }^{28}$ Zmoșu V. Un sat bucovinean de pe valea Siretului: Pătrăuții de Jos. Mărturii spirituale / Valeriu Zmoşu. - Cernăuţi: Editura Alexandru sel Bun-Zelena Bucovina, 2006. - R. 39.

${ }^{29}$ Sărbători şi obiceiuri: răspunsuri la chestionarele Atlasului Etnografic Român / [coord.: Ion Ghinoiu]. -Bucureşti: Editura Enciclopedică, 2004. - Vol. IV. - P. 7.

${ }^{30}$ Kupchanko G. Nekotoryia ..., vkaz. pracya, S. 136.

31 Constantinescu N. Dicționar Onomastic Romînesc.

București: Editura Academiei RPR, 1963, 545 p.

32 Dicționarul explicativ a limbii române (DELR), Academia Română, Institutul de Lingvistică «Iorgu Iordan»: Editura Univers Enciclopedic, 1998;

${ }^{33}$ DELR ..., vkaz. pracya, S. 147.

${ }^{34}$ Mihăilă Gh. Dictionar al limbii române vechi (sfârșitul sec. X - încep. sec. XVI). - București: Editura enciclopedică română, $1974,348 \mathrm{p}$

${ }^{35}$ Academia Română. Institutul de Lingvistică «Iorgu Iordan Al. Rosetti». Micul dicționar academic. - Vol. I-II - București: Editura Univers Enciclopedic, 2010, P. 3200

${ }^{36}$ Scriban A. Dicționarul limbii românești. - Iași: Editura Institutului de Arte Grafice «Presa bună», 1939, P. 1447.

${ }^{37}$ Encyklopediya Suchasnoyi Ukrayiny`. - T. 1. - Kyiv: KNEU - onlain-versia, 2001. Access mode: http: // esu.com.ua/

38 Encyklopedycheskyj slovar' F.A. Brokgauza y Efrona. - Sankt-Pererburg: Akcyonernoe yzdatelskoe obshhestvo F.A.

Brokgauza i Y.A. Efrona, 1890. - T. 4, $480 \mathrm{~s}$

${ }^{39}$ Manoilescu C. Înrudirea originară dintre popoarele român şi albanez. Access mode: romaniabreakingnews.ro.

${ }^{40}$ Scurtu V. Termeni de înrudire în limba română. - Bucureşti: Editura Academiei, 1966, P. 15.

${ }^{41}$ Sărbători și obiceiuri ..., vkaz. pracya, Vol. 4. - P. 7.

${ }^{42}$ Rața Gh. C. Ținutul Vatra Dornei (studiu monografic). 1993, R. 83.

${ }^{43}$ Boryak O.O. Transformacijni zminy u funkciyax babypovytuhy yak klyuchovogo personazha rodyl noyi obryadovosti // Gileya. Naukovyj visnyk. Zbirnyk naukovyh pracz' Nacional'nogo pedagogichnogo universytetu im. M.P. Dragomanova. - Vyp. 30. - Kyiv. - 2010. - S. 206.

${ }_{44}$ Boryak O.O. Instytut akusherstva $\mathrm{i}$ postat povytuhy $\mathrm{v}$ tradycijnij kulituri ukrayinciv: istoriya, rytual, mifologiya. Avtoreferat dysertaciyi na zdobuttya naukovogo stupenya doktora istorychnyh nauk za special'nistyu 07.00.05 etnologhia. / Instytut mystecztvoznavstva, fol'klorystyky ta etnologhii im. M.T. Ryl`s`kogo NAN Ukrayiny. - Kyiv, 2010, S. 33 .

${ }^{45}$ Poliovi materialy avtora.

46 Marian S.F. Nașterea la români: Studiu etnografic. București: Lito-Tipografia Carol Gobl, 1892, R. 81.

${ }^{47}$ Tam samo, S. 41, 54.

${ }^{48}$ Tam samo, S. 13-14. 


\footnotetext{
${ }^{49}$ Poliovi materialy` avtora.

${ }^{50}$ Marian S.F. Nașterea la români ..., vkaz. pracya, S. 51, 83 84.

${ }^{51}$ Poliovi materialy` avtora.

${ }^{52}$ Marian S.F. Nașterea la români ..., vkaz. pracya, S. 403.

${ }^{53}$ Ghinoiu I. Lumea de aici, lumea de dincolo ..., vkaz. pracya, R. 153.

${ }^{54}$ Gavrylyuk N.K. Kartografuvannya ..., vkaz. pracya, S. 67.

${ }^{55}$ Nesterovskyj P.A. Na severe Bessarabii ..., vkaz. pracya, S. 14.

${ }^{56}$ Cazacu P. Moldova dintre Prut și Nistru 1812-1918. -

Chișinău: Știința, 1992, R. 199.

${ }^{57}$ Spleni, Gabriel fon. Opys Bukovyny / per. z nim. O.D.

Oguya, M.M. Sajka. - Chernivci: Ruta, 1995. - S. 37.

${ }^{58}$ Smal'-Stoczkyj S. Bukovyns 'ka Rusi // Zelena Bukovyna. 1996. - N. 3-4; 1997. - N.1. - S. 32.

${ }^{59}$ SAChR. - F. N. R-938. - Op. 5. - Spr. N.. 45 A. - Ark. 2426.

${ }^{60}$ Boychuk T.M., Shkrobanecz I.D., Yuz ${ }^{\circ}$ ko O.M., Andriyecz O.A., Niczovych I.R. Istoriya rozvytku akusherstva ..., vkaz. pracya, S. 153-154.

${ }^{61}$ SAChR. - F. N. R-938. - Op. 5. - Spr. N. 45 A. - Ark. 2627.
}

${ }^{62}$ Bojchuk T.M., Shkrobanecz I.D., Yuz ko O.M., Andriyecz O.A., Niczovych I.R. Istoriya rozvytku akusherstva ..., vkaz. pracya, S. 154.

${ }^{63}$ Svyn `yn P. Statystyka ..., vkaz. pracya, S. 235.

${ }^{64}$ Kostryczkyj D.P. K voprosu o chastote ushnыx boleznej k gluhote $\mathrm{v}$ sel'skom krest'yanskom naselenii po dannym pogolovnogo osmotra zhytelej Romankouczkoj volosty Hotynskogo uezda Bessarabskoj gub.: Dys. na stepen ` d-ra med. D.P. Kostryczkogo. - SPB: Эkon. typo-lyt., 1896. - S. 5.

65 Boryak O.O. Istytut akusherstva i postat povytuhy $\mathrm{v}$ tradycijnij kul'turi ukrayinciv: istoriya, rytual, mifologiya. Avtoreferat doktorskoyi dysertaciyi ..., vkaz. pracya, S. 16, 17.

${ }^{66} \mathrm{KEV}-1873$ - N. 11. - S. 453-454.

67 Rossiya. Polnoe geograficheskoe opysanie nashogo otechestva. Pod red. V.P. Semenova-TyanShanskogo. - SPeterburg: Yzdanie A.F. Devriena, 1910, S. 553.

${ }^{68}$ SAChR. - F. N. R-938. - Op. 5. - Spr. N. 45 A. - Ark. 33.

${ }^{69}$ Boychuk T.M., Shkrobanecz I.D., Yuz ko O.M., Andriyecz O.A., Niczovych I.R. Istoriya rozvytku akusherstva ..., vkaz. pracya, S. 155.

${ }^{70}$ SAChR. - F. N. R-938. - Op. 5. - Spr. N.. 45 A. - Ark. 3338.

${ }^{71}$ Chirită Livia. Scurt istoric al asistenței medicale în România (II) // Access mode: www.medfam.ro (Medicina familiei. N.14 (decembrie 1997).

${ }^{72}$ Dobrzhans`kyj O., Makar Yu., Masan O. Hotynschyna. Istorychnyj narys. - Chernivci: Molodyj bukovynecz, 2002. - S. 219.

${ }^{73}$ Boychuk T.M., Shkrobanecz I.D., Yuz`ko O.M., Andriyecz O.A., Niczovych I.R. Istoriya rozvytku akusherstva ..., vkaz. pracya, S. 155.

${ }^{74}$ SAChR. - F. N. R-938. - Op. 5. - Spr. N.. 45 A. - Ark. 84.

${ }^{75}$ Verhrats 'kyj S. Pologova dopomoga na seli $\mathrm{v}$ umovax suchasnogo stanu medychnoyi dil'nytsi // Trudy I Vseukrayins 'kogo z'yizdu akusheriv i ghinekologhiv. Kyiv, 23-28 travnya 1927 r. (Red. G.F. Pysems 'kyj). - K, 1928. - S. 139.

${ }^{76}$ Gordiyenko V. Vidnovlennya zakladiv oxorony zdorov'ya na Bukovyni / V. Gordiyenko // Rad. Bukovyna. - 1944. -29 kvitnya.

${ }^{77}$ SAChR. - F. N. R-3. - Op. 2. - Spr. N. 753. Lystuvannya z Respublikans 'kymy narkomatamy, upravlinnyamy ta glavkamy po s/g ta promyslovyh pytannyah. -240 ark.

${ }^{78}$ SAChR. - F. N. R-938. - Op. 5. - Spr. N.. 45 A. - Ark. 124$125,128,130,200$.

${ }^{79}$ Boychuk T.M., Shkrobanecz I.D., Yuz ko O.M., Andriyecz O.A., Niczovych I.R. Istoriya rozvytku akusherstva ..., vkaz. pracya, S. 158.

${ }^{80}$ Boryak O. Trad. Kul'tura ..., vkaz. pracya, S. 16-17.

${ }^{81}$ Poliovi materialy avtora.

${ }^{82}$ Moysey A., Parajko K. Zvychayi ta obryady, pov'yazani ..., vkaz. pracya, s. 810-812.

Moysey Antoniy. Specifics of the concurrent functioning of a midwives and obstetricians in maternity rites of Ukrainian and Romanian population in Bukovyna. The proposed research deals with the process of disappearance of the one of characters in maternity rituals - the midwife (Mosha) under the pressure of new realities created by official medicine. The article is based on ethnographic and historical data of the Bukovyna region. Historiography and Source investigate presented topics in comparative perspective, shows how it was described theese problems by Romanian and Ukrainian ethnographers. Some attention was paid to terminology midwife name and its etymology. For insight into the problem by using a building material obtained during field research. It allows to the author to indicate midwifes and obstetricians function in a traditional century's period: medical, social and magical activities. The word Midwife is used for indication the person, who used own empirical knowledge before, during and after accouchement; performed special magical effect on the whole process of childbirth. As a result of her activities midwife acquired high social status in rural communities. Church cooperated with her and recognizes all midwife magical actions. Respect her job the village citizen have been protected and she enjoyed uncommon love their patients. She was one of the most respected persons for all village families, bathing, christenings, weddings and even burials.

Along with the development of the official medicine, this became progress especially in the second half of the nineteenth century. Bukovyna as a part of the Austro-Hungarian Empire and its Bessarabian part (today's Chernivtsi region), which administratively belonged to the Russian Empire, began a noticeable pressure on midwives as communities character. The article presents a statistical analysis of the growth of special medical establishmentsin the Bukovinian region during XIX - early XX centuries, until the complete disappearance of the midwife (Mosha) in public family rituals. At the same time the process followed to reduce the influence of this important character, and transformation its function and some elements of its activities.

Key words: the midwife, "mosha", the obstetrician, Bukovyna, Chernivtsi region, puerperal rites.

Мойсей Антоній - д. істор. н., проф., завідувач кафедри суспільних наук та українознавства ВДНЗ України «Буковинський держсавний медичний університет». Коло наукових інтересів: історія украӥнської культури, історія України, традииійна культура населення Буковини, взаємовпливи в сфері традииійнї культури украӥнського та східнороманського населення Буковини, прочеси етнокультурної ідентичності в прикор-донних регіонах. Автор 190 наукових праиь, в тому числі 5-х монографій.

Moysey Antoniy - Doctor of Historical Sciences, Chief of the Social Sciences and Ukrainian Studies in Higher State Educational Establishment of Ukraine «Bukovinian State Medical University». Research interests: history of Ukrainian culture, history of Ukraine, traditional culture of Ukrainian population, interplay in area of traditional culture of Ukrainian and eastromanian population of Bukovina, processes of ethnocultural identity in border regions. Author of 190 scientific publications including 5 monographs.

Received: 11-09-2016

Advance Acces Publischer: November 2016

(C) A. Moysey, 2016 